\title{
The crisis of citizenship in our time
}

\author{
Arun Sagar $^{1} \cdot$ Oishik Sircar $^{1}$
}

Accepted: 22 May 2021 / Published online: 10 June 2021

(c) O.P. Jindal Global University (JGU) 2021

\section{In our time}

The theme for this issue of Jindal Global Law Review (JGLR) is a response to a particularly troubling time during which a whole range of events coalesced to produce a palpable sense of the crisis of the ideas and lives of citizenship, in India in particular but with compelling global connects and ramifications. This issue takes ahead the inquiry that JGLR began with its Vol. 11, Issue 1 (2020) on 'Hate Crimes in India'. When we were putting together the Hate Crimes issue with our colleague and guest editor Mohsin Alam Bhat through the second half of 2019, the Hindu-nationalist and proto-fascist Bharatiya Janata Party (BJP) was bulldozing the implementation of the Citizenship Amendment Act (CAA) that would offer citizenship to refugees fleeing religious persecution from other South Asian countries-but barring Muslims. The law advances the Hindu right's commitment to shape India into a Hindu rashtra that considers it to be the holy land of Hindus alone. ${ }^{1}$

The CAA came on the heels of the drawing up of the National Register of Citizens (NRC) that the BJP was concluding in the state of Assam with the objective of separating citizens from aliens by identifying and deporting 'foreigners'. The project had the disastrous consequence of producing the world's largest group of stateless people by denying them citizenship status if they were not able to produce legacy papers. A majority of these people were Muslims, and the government was building massive detention centres in Assam and other parts of India to incarcerate those who get disqualified as citizens and are thus rendered stateless before deportation. In a country where being sans-papiers-without identity documents like the ration card, or the voter's identity card, or birth certificates-is the condition of being marginalised, the NRC project intensified the distance, both materially and metaphorically, between citizens and their access to state institutions, bureaucracy

\footnotetext{
${ }^{1}$ Mohsin Alam Bhat, 'Stateless and Hyperlegalized: The Indian State Weaponizes Paperwork' (The Baffler, 3 January 2020). https://thebaffler.com/logical-revolts/stateless-and-hyperlegalized-alam. Accessed 20 May 2021.
}

Arun Sagar

asagar@jgu.edu.in

1 O. P. Jindal Global University, Sonipat, India 
and documentation. ${ }^{2}$ The project continues to be BJP's ideological commitment to a Hindu rashtra, perversely justified in the languages of national security, welfare, rights, and development. This was not even a conceit—as made apparent by the Home Minister Amit Shah, when he characterised undocumented Muslim Bangladeshis in India as 'termites' who he will ensure are thrown into the Bay of Bengal. ${ }^{3}$ This Islamophobic invective has been accompanied by the Indian state's, including the Supreme Court of India's, decision to deport Rohingya asylum seekers back to Myanmar where they are facing persecution because of their religious identity. ${ }^{4}$ The CAA offered no assistance to them, and goes against the jus cogens principle of non-refoulement in international refugee law. ${ }^{5}$

In response to these developments that could irreversibly disenfranchise an already marginalised minority community of Indian Muslims, ${ }^{6}$ elderly Muslim women gathered in Delhi's Shaheen Bagh to start an indefinite protest against the CAA-NRC-NPR (National Population Register) triad. The NPR is proposed to be the prototype of the NRC (which was limited to Assam) but applicable to the whole of India. The Shaheen Bagh protests-mobilised in the wake of the Delhi Police's indiscriminate violence against students of Jamia Millia Islamia and Jawaharlal Nehru University - grew in massive strength with a whole range of other civil society actors in anti-caste movements, student activists, and ordinary citizens, among others, joining in solidarity. Versions of Shaheen Bagh began in other parts of Delhi and also spread to other parts of India. Never before had India seen such a non-centralised yet concerted non-violent resistance in the context of ordinary people, led by Muslim women, claiming acknowledgement and space-both public and symbolic - as citizens. The BJP government tried various forms of intimidation, deploying the police and their non-state militant cadres who used threats of violence to disperse the protestors, without avail. ${ }^{7}$

As the anti-CAA protests mobilised more and more people to join in solidarity across India and in the diaspora, we saw the unleashing of a pogrom singularly targeting Muslims in North East Delhi-as always with active involvement of the police, BJP politicians, and other Hindu right-wing militant outfits. The North East

\footnotetext{
2 Talha Abdul Rahman, 'Identifying the "Outsider": An Assessment of Foreigner Tribunals in the Indian State of Assam' (2020) 2(1) Statelessness \& Citizenship Review 112.

${ }^{3}$ Devjyot Ghoshal, 'Amit Shah Vows to Throw Illegal Immigrants Into Bay of Bengal' (Reuters, 12 April 2019). https://www.reuters.com/article/india-election-speech-idUSKCN1RO1YD. Accessed 20 May 2021.

${ }^{4}$ Nizamuddin Ahmad Siddiqui \& Abu Zar Ali, 'Supreme Court Order Allowing Deportation of Rohingyas Shows That India Hasn't Shed Partition Baggage' (Scroll.in, 18 April 2021). https://scroll.in/article/ 992447/supreme-court-order-allowing-deportation-of-rohingyas-shows-that-india-hasnt-shed-partitionbaggage. Accessed 20 May 2021.

5 Jean Allain, 'The Jus Cogens Nature of Non-Refoulement' (2001) 13(4) International Journal of Refugee Law 533.

${ }^{6}$ Bilal Kuchay, 'In India’s Democracy, Muslims Feel Increasingly Marginalised' (Al Jazeera, 24 April 2019). https://www.aljazeera.com/news/2019/4/24/in-indias-democracy-muslims-feel-increasingly-margi nalised. Accessed 20 May 2021.

${ }^{7}$ Shuddhabrata Sengupta, 'The Garden of Freedom: Lessons That Shaheen Bagh Teaches Us About Citizenship' (The Caravan, 2 February 2020). https://caravanmagazine.in/politics/lessons-that-shaheenbagh-teaches-us-about-citizenship. Accessed 20 May 2021.
} 
Delhi pogrom - as has historically been the case with anti-minority mass violencewas meant to both show Muslims their place for claiming their space and place as citizens in the language of the Constitution, and also to demonstrate the BJP's fascist commitment to the idea of a Hindu rashtra. ${ }^{8}$ At this time in early 2020, Covid-19 cases had already started surfacing in India and before the nation-wide lockdown was announced in March, the Shaheen Bagh protesters were evicted. By this time, a range of arrests had already been carried out based on trumped-up charges against young student activists accused of fomenting the anti-CAA protests. ${ }^{9}$

While the state busied itself to carry out more arrests of civil rights activists and human rights lawyers based on flimsy evidence in the name of protecting national security-included those who have come to be called the Bhima Koregaon $16^{10}$ the imposition of the world's strictest Covid-19 lockdown, announced without any preparation, resulted in a dehumanising experience for lakhs of India's migrant workers who, owing to their economic and social precarity, started walking thousands of miles from the cities where they worked back to their villages. Many died on their journeys not being able to take the toil, the heat, or find food. Those who lived were sprayed with noxious disinfectants when they crossed state borders, as if they were the virus themselves. Little did the state, that was so swift with apprehending dissenters, do to take care of its own poor citizens left to fend for themselves and die on the major highways that India boasts of as its arteries of trade and economic development. ${ }^{11}$

That marginalised citizens deserve to die if they cannot take care of themselvesthey are the 'agents of their own abuse', ${ }^{12}$ harm and misfortune-was perversely captured in the putatively motivational slogan popularised by Prime Minister Narendra Modi: Aatmanirbhar Bharat or Self-reliant India. ${ }^{13}$ That in a socialist, secular democracy, reliance is not about responsibilisation but about the responsibility to care and the ethos of what Ambedkar called 'associated living' ${ }^{14}$ was lost on the

\footnotetext{
${ }_{8}$ Prabhjit Singh and Arshu John, 'Crime and Prejudice: The BJP and Delhi Police's Hand in the Delhi Violence' (The Caravan, 1 September 2020). https://caravanmagazine.in/politics/the-bjp-and-delhipolice-hand-in-the-delhi-violence. Accessed 20 May 2021.

9 Sruthisagar Yamunan, 'As Delhi Police Use Lockdown to Arrest Anti-CAA Activists, Courts Must Act to Check Abuse of Power' (Scroll.in, 26 May 2020). https://scroll.in/article/962930/as-delhi-police-uselockdown-to-arrest-anti-caa-activists-courts-must-act-to-check-abuse-of-power. Accessed 20 May 2021.

10 The Polis Project, 'Manufacturing Evidence: How the Police is Framing and Arresting Constitutional Rights Defenders in India' (2020). https://thepolisproject.com/wp-content/uploads/2020/08/Manufactur ing-Evidence-.pdf. Accessed 20 May 2021.

11 Upendra Baxi, 'Exodus Constitutionalism: Mass Migration in Covid Lockdown Times' (The India Forum, 3 July 2020). https://www.theindiaforum.in/article/exodus-constitutionalism. Accessed 20 May 2021. See Ranabir Samaddar (ed.), Borders of an Epidemic: COVID 19 and Migrant Workers (Mahanirban Calcutta Research Group 2020).

12 Jacqueline Rose, 'Agents of Their Own Abuse' (2019) 41(19) London Review of Books. https://www. lrb.co.uk/the-paper/v41/n19/jacqueline-rose/agents-of-their-own-abuse. Accessed 20 May 2021.

13 Sagar, 'Scriptural Economy: Modi's Atmanirbhar Bharat is a Thinly Veiled Blueprint of the RSS's "Hindu Economics", (The Caravan, 23 July 2020). https://caravanmagazine.in/politics/narendra-modiatmanirbhar-bharat-rss-hindu-economics-rashtra. Accessed 20 May 2021.

14 B. R. Ambedkar, Annihilation of Caste (3rd edn 1944) 24.
} 
hashtag and publicity management machinery of the Modi government. And the devastating second-wave of Covid-19 in India in 2021 bears ongoing testimony to the "social murder" 15 of the sick and the poor caused by the violence of state negligence, apathy and complete disregard for its citizens' right to not only access nondiscriminatory health care and free vaccines, but also to die with dignity. It is not a surprise that commentators have been calling the Indian state's actions and inactions in response to the second-wave a crime against humanity, and demanding the holding of truth commission hearings. ${ }^{16}$

\section{Law and line-drawing}

In this issue, we were keen to consider the role that modern law is recruited to play in the experiences of dispossession produced in and through discourses of citizenship. If modern law was born from the birth of Westphalian sovereignty, the sovereign authority's task was to use the law-as a combination of commands, rules, norms, morals, and exceptions - to produce intelligible categories that could then be organised on a hierarchical scale of values.

Producing categories requires the deployment of force-both material and metaphorical - by the sovereign authority (this could be state, proto-state and non-state formations) to draw lines that divide and distinguish the citizen from the non-citizen, the insider from the outsider, the human from the slave, the Brahman from the Dalit, the heterosexual from the queer, the resident from the refugee, the landed from the landless, the mortal from the divine, the city from the village, the border from the wall, the government from the corporation, and the state from the church. Such line-drawing activity continues to be a part of liberal democratic governance, and modern states justify the performance of this authority in the rationalising discourses of sovereignty, governance, the rule of law, national security, human rights, and development. So seductive are these discourses of modern state-craft that they seamlessly merge family values and fascism. ${ }^{17}$ The sophisticated coming together of neoliberalism and Hindutva in India today is an instance of how a mutating form of sovereign authority is producing new ideas about citizenship, belonging, assimilation, and annihilation. ${ }^{18}$

\footnotetext{
15 Kamran Abbasi, 'Covid-19: Social Murder, They Wrote-Elected, Unaccountable, and Unrepentant' (BMJ, 4 February 2021). https://www.bmj.com/content/372/bmj.n314. Accessed 20 May 2021.

${ }^{16}$ See Arundhati Roy, "We Are Witnessing a Crime Against Humanity': Arundhati Roy on India's Covid Catastrophe' (The Guardian, 28 April 2021). https://www.theguardian.com/news/2021/apr/28/ crime-against-humanity-arundhati-roy-india-covid-catastrophe. Accessed 20 May 2021. See also Abhinav Verma and Radhika Roy, 'Why India Needs to Set Up a Truth Commission to Help It Really Heal from the Covid-19 Pandemic' (Scroll.in, 13 May 2021). https://scroll.in/article/994754/why-indiashould-set-up-a-truth-commission-to-help-it-truly-heal-from-the-covid-19-pandemic. Accessed 20 May 2021.

${ }^{17}$ See Wendy Brown, Undoing the Demos: Neoliberalism's Stealth Revolution (Princeton University Press 2015).

${ }^{18}$ See Anand Teltumbde, Republic of Caste: Thinking Equality in the Time of Neoliberal Hindutva (Navayana 2018).
} 
And yet, despite our critical assessment of the monopoly of violence to which sovereignty continues to lay claim-both as a rule and as an exception-through the law, ${ }^{19}$ it is the law that the disenfranchised, marginalised, and the subaltern return to over and over again to resist and challenge that very monopoly of violence. Is this a move in earnest? Or is this also part of modern state-craft, where a contingent and inescapable faith in the law's 'spectacles of emancipation' 20 as independent from the state and thus incorruptible - is kept alive as a means to anesthetise the possibility of collective resistance? And when such resistance happens-like a Shaheen Bagh that waves the Constitution in the face of the sovereign to show it its place ${ }^{21}$ the state uses the exceptions within that very document of promise and progress (notably the preventive detention exception) to incarcerate the dissident citizen. ${ }^{22}$ Paradoxically, it is the same dissident citizen who draws strength from the Constitution to claim their freedoms to question the sovereign's breach of constitutional standards.

So, it is not just the sovereign who recruits the law in the line-drawing between the citizen and the dissident, but so does the dissident who deploys the law to draw lines between what is just and what is unjust. And likewise, both the sovereign and the dissident citizen step out of the language of the posited law to cite moralityboth constitutional and extra-constitutional-as their driving motivations. The line drawing still continues and, possibly, law itself undergoes re-imagination-sometimes regressive, sometimes radical, sometimes reformist-in the process.

The law in the discourse of citizenship is thus a 'pharmakon'-simultaneously, medicine, poison, and scapegoat. ${ }^{23}$ It is shapeshifting, malleable, and increasingly mutating. And yet, despite this polysemic possibility that an inquiry about the relationship between law and citizenship might open up and deserves exploration to better understand the violence of our times, it can only do so by constantly attending to the role that power plays in the way line-drawing operates. ${ }^{24}$ Who is drawing the line? Who is manufacturing the border? Who decides who gets to stay in and who is pushed out? In whose language do you need to speak to be heard by the authority that draws the line in the first place? And if there are many lines being drawn by rival authorities simultaneously, might these lines sometimes meet in an encounter of hospitality, or might some lines get erased in the conduct of sovereign hostility? ${ }^{25}$

\footnotetext{
${ }^{19}$ Andreas Anter, 'The Modern State and Its Monopoly on Violence' in Edith Hanke, Lawrence Scaff, and Sam Whimster (eds.), The Oxford Handbook of Max Weber (Oxford University Press 2019).

${ }^{20}$ Oishik Sircar, 'Spectacles of Emancipation: Reading Rights Differently in India's Legal Discourse' (2012) 49(3) Osgoode Hall Law Journal 527.

${ }^{21}$ Rahul Rao, 'Test of Faith: The CAA Protests Shake the Old Bounds of Indian Secular Morality' (The Caravan, 30 January 2020). https://caravanmagazine.in/politics/caa-protests-shake-old-bounds-indiansecular-morality. Accessed 20 May 2021.

${ }^{22}$ Oishik Sircar, 'Postcolonial Liberalism's Double Binds' (Critical Legal Thinking, 19 June 2020). https://criticallegalthinking.com/2020/06/19/postcolonial-liberalisms-double-binds. Accessed 20 May 2021.

${ }^{23}$ Barbara Johnson, 'The Pharmakon' in Barry Stocker (ed.), Jacques Derrida: Basic Writings (Routledge 2007).

${ }^{24}$ Irene Watson, 'Buried Alive' (2002) 13(3) Law and Critique 253.

${ }^{25}$ Sundhya Pahuja, 'Laws of Encounter: A Jurisdictional Account of International Law' (2013) 1(1) London Review of International Law 63.
} 
Our work on this issue was accompanied by an urgent sense of foreboding. We wanted our voice to carry some palpable sense of the times that we are in and writing from. The pieces that this issue of JGLR carries quite appropriately slow down the sense of discontent that we have expressed. This is appropriate because, even though the motivation behind choosing the theme for this issue was to find a way to mark the urgency of the moment we were and continue to be in, we feel scholarly endeavours might do well to try and resist the demands of spontaneity and immediate outrage that social media and op-ed culture promote. We want to draw our own line here, not because we feel one form of inquiry carries more value than another, but to acknowledge the commitment to the conventions of a genre-that of the scholarly article or essay. To wrestle with a convention even as we try to re-cast and re-imagine that convention is the demonstration of an ethical commitment to the craft of scholarship in the humanistic tradition. The pieces that we have curated for this issue on the relationship between law and citizenship attempt to undertake such a task that takes both the work of politics (as a commitment to praxis) as well as that of critique (as a form of writing practice) seriously. The issue opens up the conversations on the theme in directions that the putatively provincial expression 'our times' does not capture adequately. When the range of topics covered by the pieces are read together, we see a more planetary understanding of 'our times' emerge ${ }^{26}$ - one that negotiates, struggles, rehabilitates, cares, repairs and frustrates the possibilities and perils of law's line-drawing.

\section{The contributions}

Since citizenship is the legal expression of belonging, the notion of 'citizen' carries with it that of the non-citizen, the 'alien'. And so, the determination of citizenship to constitute the subject-member of the state has as its necessary corollary the determination of the non-citizen, the object of exclusion. This tension between the constitutive and restrictive or exclusionary aspects of citizenship comes sharply into focus when it is layered or multifaceted, or when two citizenships are inextricably linked. Thibault Weigelt examines the 'crisis' of citizenship in the European Union, where EU citizenship is contingent upon citizenship in the EU member States. This unique legal framework brings into question the very meaning of citizenship-what rights should be associated with it? Is it possible to have two independent citizenships 'superimposed' on one another? And how are human rights - as imagined under international law - to be protected within a multi-layered citizenship framework?

This latter question becomes of central importance due to the immense material consequences of a denial of citizenship, among which the problem of statelessness is the most perplexing. Statelessness is the dark shadow that haunts citizenship; if citizenship by its very nature involves the possibility of exclusion, statelessness is

\footnotetext{
26 Torbjørn Tumyr Nilsen and Sindre Bangstad, 'Thoughts on the Planetary: An Interview with Achille Mbembe' (New Frame, 5 September 2019). https://www.newframe.com/thoughts-on-the-planetary-aninterview-with-achille-mbembe/. Accessed 20 May 2021.
} 
a universal exclusion. In addition to Weigelt's discussion of it in the context of the EU, this issue carries comments on two cases involving statelessness in two other jurisdictions. Aashish Yadav examines an Indian judgement that reveals the extent to which the Indian legal framework ignores the phenomenon of statelessness. The analysis also reveals how Indian citizenship law and practice leaves millions under the threat of statelessness through deprivation of nationality. Arafat Ibnul Bashar highlights similar legal problems in Liberia, through a discussion of a case involving constitutional challenges to the 'automatic' loss of citizenship in certain situations, and an illustration of its possible consequences.

The violence that legal processes and interpretations can inflict is a central theme in most of the contributions. It is directly addressed by Prashant Singh and Anubhav Dutt Tiwari in their work on the citizenship framework in Assam. Singh and Tiwari conduct an in-depth historical analysis of the law and politics of citizenship to show how the figure of the 'illegal migrant' has been discursively constituted as the focus of both immigration law and citizenship law in India, and how the establishment of the NRC and its reliance on identity documents has created a class of 'residual citizens' particularly susceptible to the law's violence. Like any legal framework, citizenship is inevitably reliant on documents, evidence, procedure-indeed, it is impossible to imagine a citizenship 'regime' that does not rely on documentation. Yet, the requirement of documentation and the insistence on verifying their authenticity can itself become a tool of domination in certain socio-economic contexts.

Priya Mathur looks at how sexual identity is constructed by citizenship and immigration law in Canada. She describes how the law enforces a heteronormative structure on queer applicants; strikingly, her historical analysis shows that the narrative of a progressive reduction in hostility to queer identities is belied by the actual operation of the legal framework in even its most 'progressive' iteration. In addition to the fact that couples applying for visas or refugee status are expected to conform to a heteronormative imagination of their relationship, Mathur highlights how the translation of non-Western familial arrangements and social contexts for the purpose of immigration law creates many difficulties for applicants.

Nabanita Samanta examines an entirely different level of precariousness, that which is experienced in the context of climate-induced displacement. She explores how such displacement forces us to not only think about the acknowledgement (or rather, the lack of acknowledgement) by the legal apparatus of the impact of climate change, but also to engage with the many ways in which climate change problematises our basic understandings of politics and society.

Just like the determination of citizenship, drawing a border is an expression of power; the object (the state) is mastered in the very act of its constitution. This is especially clear in colonial contexts. Aman Kumar explores how one such colonial border, that between India and Nepal, continues to disrupt not only political relations between the now independent states but also the life-worlds of the people on either side of it. The author's historical analysis leads him to question on the one hand the very purpose of borders and how it changed in the context of colonialism and, on the other, the international law principle of uti possedis, which maintains the existing borders in place. 
The act of making a border is also the focus of Achia Anzi's contribution, in which he looks at two art exhibits with work by artists from North-East India. As both an expression of the subject in the world and as a site for the discursive inscription-and performance-of citizenship in the popular consciousness, the arts and popular culture are crucial locations for the study of citizenship. The works examined in this contribution put not the physical markers of the border but the map itself at the centre of our gaze. The map is where the border takes shape, takes meaning; at the same time, it is the border that creates space, and by doing so creates a locus for political struggles of identity and belonging.

Hannah Anzi focuses her analytical gaze on the film 5 Broken Cameras, in which the border emerges as a space of resistance; however, the border is itself a violence, a separation of the citizen from the less-than-citizen, where once again we see how the physical demarcation of the boundary is itself the mechanism for the constitution of the subject's political status as the object of power.

Uttaran Das Gupta addresses the gendered performance of citizenship through his evocation of the parallels between women's resistance in the film Mirch Masala and the protest at Shaheen Bagh. The implicit analogy between discriminatory and exclusionary citizenship (the object of the protest) and the film's focus on sexual exploitation is striking, and troubling. The locked door in the film is a metaphor for borders in general: both restrictive of freedom and constitutive of the community that makes freedom possible.

Cultural analysis and personal narrative combine in Dikshit Sarma Bhagabati's contribution, which explores how narratives of identity and representations of the outsider construct the lived experience of citizenship in Assam. The use of the autotheoretical voice allows the author to situate the reader in this experience, and to see how nationalism can instrumentalise linguistic and communitarian bonds even when the construction of national identity itself tends to exclude those in the 'margins'. The resultant narrative's perspective on identity is one of both hesitance and assertion; in the particular context of Assam, the legal discourse of citizenship is intended to suppress and/or channel these emotive conflicts.

We thus see across this range of contributions how citizenship and borders create both the imaginative and the physical spaces in which our subjectivities are constituted and our life-worlds exist, sometimes peacefully, sometimes as experiences of violence, but always as implicit or explicit manifestations of the dichotomy of self and other. Indeed, this dichotomy emerges as the very basis of modern social and political life. The law of citizenship, its procedures, its definitions that include and exclude, its creation of the bearer of rights and the illegal alien-these combine with the discursive formulations of identity, community and belonging that create language, thought and culture, and are at the same time created by them. This issue of the JGLR is intended to make a rich contribution to our understanding of these phenomena.

Publisher's Note Springer Nature remains neutral with regard to jurisdictional claims in published maps and institutional affiliations. 